\title{
Judicial Control of the Riot Curfew
}

Urban riots were more numerous and costly during the past year than ever before; ${ }^{1}$ it is quite possible that they will be worse during the current summer. Yet legislative programs to eliminate the social ills underlying riots are proceeding at a painfully slow pace..$^{2}$ Both a cause and an effect of this delay has been an emphasis on the shortrun goal of quashing disturbances. ${ }^{3}$ Along with tanks and other armaments, ${ }^{4}$ the curfew ${ }^{5}$ is rapidly becoming one of the most popular riot control devices in the government official's arsenal. ${ }^{\circ}$

1. The Report of the National Advisory Commission on Givil Disorders (advance copy, Bantam ed. (1968) [hereinafter cited as RIOT COMM'N REPORT] lists 164 disorders which occurred during the first nine months of 1967. Id. 113. No tabulation of disorders in past years was included. Other sources list fewer disorders in 1967, but confirm a pattern of increase in the extent of rioting during 1967 as compared with previous years. E.g., Hear. ings on Riots, Civil and Criminal Disorders Before the Permanent Subcomm. on Investiga: tions of the Senate Gomm. on Government Operations, 90th Cong., 1st Sess., pt. 1, facing 15 (1967) [hereinafter cited as Hearings on Riots] (75 disorders in 1967, 21 in 1966 atnd 5 in 1965). There were a substantial number of disorders in the first and second weck of April, 1968, following the death of Dr. Martin Luther King, Jr. The New York Times listed 110 cities which experienced racial violence during this period. N.Y. Times, Apr, 10, 1968, at 37 . col. 3. At least one disorder, in Orangeburg, s.C., occurred during the early months of 1968. See N.Y. Times, Feb. 10, 1968, at 23, col. 3.

The Senate Subcommittee on Investigation reported 84 deaths and 1,950 injurics in the 1967 riots it studied, as compared to 10 deaths, 467 injuries in 1966, and 36 deaths, 1,206 injuries in 1965. Hearings on Riots, facing 15. The Subcommittee estimated financlat loss in 1967 at $\$ 664.5$ million, compared to $\$ 10.2$ million in 1966 and $\$ 40,150,000$ in 1965 . Id. Because a number of cities surveyed did not provide estimates of financial loss, actual losses from rioting in all cities in each year are likely to have been substantially greater. In the aftermath of Dr. King's death last spring, the New Yorh Times reported 46 deaths, N.Y. Times, Apr. 24, 1968, at 30, col. 6, and $\$ 45$ million in losses to uninsured property alone. N.Y. Times, Apr. 13, 1968, at 13, col. 1.

Although the riots of the past several years were far more numcrous and destructive, there have been many racial disturbances, often including fighting between whites and blacks, in the nation's history. Some, for example East St. Louls in 1917, Chicago in 1919, and Detroit in 1943, were serious. See generally RIOT COMM'N REPORT 206-35; A. I. WHSKOW, FROM RACE RIOT TO SIT-IN (1967).

2. Of numerous proposals made by the Riot Commission in the areas of employment, education, welfare and housing, including the creation of 2 million jobs in the next threc years for the hard-core unemployed and a guaranteed annual income, see Rior CoMM'N REPORT 23-29, 410-83, only one of any substance, open housing legislation, had been en. acted by Congress as of early July. The open housing bill itself, passed soon after the death of Dr. King, might not have been enacted if he had not been slain.

3. Hopefully the most extreme example was Mayor Richard J. Daley's April 15 in. struction that Chicago policemen were "to shoot to kill" arsonists, to "maim or cripple" looters, and to use Mace on children. N.Y. Times, Apr. 16, 1968, at 28, col. 3. Dalcy later said that mail was running 10 to $I$ in favor of his stand. Id., Apr. 21, 1968, § E, at 3 , col. 1 .

The United States Army has earmarked a dozen brigade-size $(2,000 \mathrm{men})$ task forces for special training in riot control, id., Apr. 24, at 1, col. 2, and has "stockpiled riot-control gear in strategically situated depots . . . ready to airlift... to any city if the necd arises." Id., Mar. 2, 1968, at 16, col. 3.

4. Los Angeles was reported interested in the purchase of a 20-ton armored personncl carrier which can carry 20 men in bulletproof safety, and can be equipped with a .30 . caliber machine gun, tear gas launchers, a smoke-screen device, chemical fire extinguishers and a siren that can disable people with its sound. Detroit used five armorcd vehicles during its riot last summer, and several of its neighboring counties have since purchased similar vehicles. Chicago has opted for helicopters. N.X. Times, Mar. 2, 1968, at 16, col. 8. 
Because of their simplicity, curfews can be used in a thoughtless manner at times when they can fulfill no valid governmental policy and can aggravate the very conditions which cause riots. Furthermore, curfews impose drastic limitations on individual liberty which are foreign to a free society. The circumstances under which a curfew may be imposed, its duration, and geographic scope must be subject to close judicial scrutiny.

\section{Nature and Use of the Curfew}

\section{A. History}

The imposition' of curfews on entire urban populations is nearly unprecedented in American history. Prior to its use in response to rioting in Philadelphia and Rochester in 1964 and Watts in 1965, the only examples of general curfews which can be found are those

Virginia's state police ordered six armored cars costing $\$ 30,000$ each. SAt. ErE. Post, Apr. 20, 1968, at 28.

5. A curfew is a law requiring persons to remain indoors during specified periods, usually the night time. Ordinarily certain exceptions are permitted, although these may vary from limited categories of official personnel performing essential functions to persons engaged in "legitimate" or "reasonable" activity, e.g., coming to and going from vork. The greater the number of exceptions of the latter type, the more a curfew becomes simply the functional equivalent of a loitering statute.

6. On the basis of a tabulation derived from reports in the New York Times, it ap. pears that curfews were imposed in at least twenty-two cities last summer, although three were applied only to juveniles. The cities were: Atlanta, Ga., Cairo, Ill., Detroit, Mich., Elgin, Ill., Elizabeth, N.J., Grand Rapids, Mich., Milwaukec, Wis., Mrt. Vernon, N.X.. Newark, N.J., New Brunswick, N.J., New Haven, Conn., Pecskill, N.Y., Phoenix, Ariz, Plainfield, N.J., Providence, R.I. (juveniles), South Bend, Ind., Syracuse, N.Y., Tampa, Fla., Toledo, Ohio (juveniles), Waterloo, Iowa (juveniles), Wichita, Kan., and Wilmington, Del. This figure is twice as large as the eleven reported by the Riot Commission. Rror COMM'N REPORT 125, 169 n.80.

Curfews appear to have grown more popular after the summer. One was imposed in response to February disturbances in Orangeburg, S.C. In the wave of rioting and feared disturbances which followed the death of Dr. Martin Luther King, the device was imposed upon at least twenty-seven cities: Albion, Mich., Baltimorc, MId., Chattanooga, Tenn., Chicago, Ill., Cincinnati, Ohio, Detroit, Mich., Joliet, Ill., Kansas City, Mo., Memphis, Tenn., Mobile, Ala., Nashville, Tenn., Newark, N.J., Pine BluIf, Ark, Pittsburgh, Pa., Trenton, N.J., Washington, D.C., W'ilmington, Del., Youngstown, Ohio, and nine North Carolina cities-Charlotte, Concord, Durham, Goldsborough, Greensboro, Greenville, Raleigh, Wilmington, and Wilson.

Most curfews have applied only during the night, although a few have begun in late afternoon and Milwaukee's was imposed round the clock for a 26-hour period. They have as a rule had very narrow, if any, explicit exceptions, generally allowing policemen, firemen, other important officials and newsmen to come outside.

Several cities have employed measures, somewhat analogous to curfews, limiting the permissible size of public gatherings. Last summer, Philadelphia, $\mathrm{Pa}$., and Wilmington, Del., proscribed crowds larger than twelve and ten respectively. Philadelphia again (12) and Pittsburgh (10) used crowd-control measures this spring. Arorcover, in numerous cities, bars, liquor and gun stores, gasoline stations, and other business establishments were closed or their sales retricted.

7. See N.Y. Times, July 29, 1964, at 1, col. I (Rochester); id., Aug. 31, 1964, at 1, col. 5 (Philadelphia); id., Aug. 18, 1965, at 1, col. 2 (Watts). 
imposed on Detroit during its race riots in $1943^{\circ}$ and in New Castle, Indiana, in response to labor riots in $1956 .^{\circ}$ There are no reported decisions challenging these measures. A curfew in Portland, Oregon, which made it unlawful to be on the streets between 1:00 and 5:00 a.m. "without having and disclosing a lawful purpose" was upheld by the Oregon Supreme Court in 1949.10

Curfews have generally been directed at specific groups. There are still a large number of juvenile curfews, ${ }^{11}$ although their validity is an unsettled question about which the few state courts that have addressed the issue have differed.12 In the pre-Civil War era, some curfews were imposed solely upon Negroes. ${ }^{13}$ The most notorious curfew is that imposed during World War II on Japanese-Americans in California to prevent espionage and sabotage; the Supreme Court upheld

8. The curfew required that all persons not having important business, or going to or from work, be off the streets and in their place of abode between 10 pan, and 6 at.1n. Places of amusement were closed from 9 p.m. to 7 a.m. See NATIONAL. INST. OF MUNiciral Law Officers Rep., Municipal CuRfew for Minors-Model Ordinance AnNotatrid (No. 99, 1943).

9. For a discussion of the New Castle rioting and the use of a curfew and other meat sures taken pursuant to a declaration of martial law, see Note, Rule by Martial Latu in Indiana: The Scope of Executive Power, 31 IND. L. Rev. 456 (1956).

10. City of Portland v. Goodwin, 187 Ore. 409, 210 P.2d 577, rehearing denied, 187 Ore. 430,210 P.2d 586 (1949). The curfew appears more akin to a loitering statute than thoso which have recently been employed. Moreover, the court limited its application cven further. Apparently disturbed because the ordinance, taken literally, shifted the burden of proof to the defendant and specified no prohibited act other than presence on the street, it interpreted the regulation to make nocturnal presence on the strect unlawful only if a person "has and by conduct discloses a purpose to violate a law other than the ordinance." Id. at 431, 210 P.2d at 586. See also Note, Use of Vagrancy.Type Lat's for Arre'st and Detention of Suspicious Persons, 59 Yale L.]. 1351 (1950).

11. No complete figures have been compiled on the prevalence of juvenile curfews in America. However, a 1958 survey indicates that of 103 responding citics with populations greater than 100,000, 57 had curfew ordinances in effect. See Note, Curfew Ordinances and the Control of Nocturnal Juvenile Crime, 107 U. PA. L. REv. 66, 68 (1958).

12. Neither the Supreme Court nor the lower federal courts have been presented with a juvenile curfew case. Existing state authority is of little assistance in analyzing the cone stitutional problems involved-the particular ordinances which were approved or rejected do not contain many features which might meaningfully serve as significant points for distinguishing the valid from the invalid regulatory measure. Compare Thistlewood $v$ Trial Magistrate for Ocean City, 236 Md. 548, 204 A.2d 688 (1964), and Pcople v. Walton, 70 Cal. App. 2d 862, 161 P.2d 498 (1945) (valid), with Alves v. Justice Court of Chico Judicial Dist., 148 Cal. App. 2d 419, 306 P.2d 601 (1957) and Ex parte McCarver, 39 Tex. Crim. 448, 46 S.W.936 (1898) (invalid). See also, Note, supra note 11, 107 U. PA. L. REv. 66 (1958).

A fundamental basis of those cases which have upheld juvenile curfews is the right of the state to subject minors to greater regulation than adults. See, e.g., Thistlewood v, Trial Magistrate for Ocean City, supra at 557, $204 \mathrm{A.2d}$ at 693.94. It is not clear after In re Gault, 387 U.S. 1 (1967), that regulation on such a basis is as clearly acceptable as the courts seem to have thought.

13. Montgomery, Ala., imposed such a curfew. See Note, supra note 10, 59 YAtE L.J. 1351, 1354 n.12. A similar measure in Memphis, Tenn., prohibiting Negroes from the streets after 10 p.m., was declared unconstitutional as applied to a free Negro in Mayor of Memphis v. Winfield, 27 Tenn. 707 (1848). 
this as a valid exercise of the war power. ${ }^{14}$ Hawaii was placed under another severe wartime curfew. ${ }^{15}$

\section{B. Present Role ${ }^{16}$}

A curfew has several desirable features as a method of riot control. It minimizes confusion by providing law enforcement officers and persons in the curfew area with a rule which is easy to understand and apply: no one may be on the streets. The successful curfew will help prevent the development of a "carnival atmosphere," which leads many citizens who are initially bystanders to join in rioting. The voluntary compliance that can be expected from uncommitted potential rioters may eliminate the crowds which feed a riot and which provide cover for those individuals bent on destruction. Cities like Milwaukee in which curfews seemed effective in quelling riots imposed them at an early stage when potential rioters had not gathered in large numbers. ${ }^{17}$

14. Hirabayashi v. United States, 320 U.S. 81 (1949); Yasui v. United States, 320 U.S. 115 (1943). The Supreme Court subsequently upheld even more drastic messures. See Korematsu v. United States, 323 U.S. 214 (1944) (orders forbidding Japanese-Americans from living in certain areas); Ex parte Endo, 323 U.S. 283 (1944) (assuming the validity of detention in Relocation Centers although ordering release after period of time had elapsed during which loyalty could have been determined).

These cases have been strongly criticized. See, e.g., ten Brock, Wartime Pou'er of the Military Over Citizen Civilians Within the Country, 41 CALIF. L. REv. 167 (1953); Rostow, The Japanese-American Cases-A Disaster, 54 Yale L.J. 489 (1945); Dembitz, Racial Discrimination and the Military Judgment: The Supreme Court's Korematsu and Endo Decisions, 45 Colum. L. REv. 175 (1945); Alexandre, The Nisei-A Casualty of World War II, 28 CORNELL L.Q. 385 (1943).

The Supreme Court refused generally to review military discretion "in determining the nature and extent of the threatened injury or danger and in the selection of means for resisting it." Hirabayashi v. United States, 320 U.S. 81,93 (1943). Among the unquestioned military judgments was that regarding the likelihood of espionage and sobotage by persons of Japanese heritage: "The fact that no sabotage has taken place to date is a disturbing and confirming indication that such action will be taken." Korcmatsu v. United States, 323 U.S. 219, 241 n.15 (dissenting opinion of Mrurphy, J.).

15. A blackout and curfew began on the night of Deecmber 7,1941 , and continued for more than two years, long "after it could reasonably be said to be necessary." J. Axtrioss;, HAWAII UNDER ARAYY RULE 59 (1955).

16. For a discussion of the use of curfews during the past jear, sce note 6 supra.

17. Within several hours of an outbreak of rioting in Milwakkec late Sunday cvening. July 30, Mayor Henry Maier imposed a round-the-clock, city-wide curfew and called for the National Guard. N.Y. Times, Aug. 1, 1967, at 1, col. 4. It was reported that there were three deaths, approximately 100 injuries and relatively light property damage, although economic loss caused by the curfew "mounted into the millions." Id., Aug. 4, at 12 , col. 2.

A similar strategy was employed with some success in disturbances after the Milwakee rioting. See, e.g., N.Y. Times, Aug. 18, 1967, at 1, col. 2 (S)racuse); id., Aug. 21, 1967, at 1. col. 2 (New Haven). It seemed even more popular this spring. See, c.g., id., Apr. 5, 1968, at 1, col. 8 (Miemphis); id., Apr. 6, 1968, at 1, col. 8 (Washington); id., at 22, col. 7 (Detroit); id., Apr. 7, 1968, at 1, col. 6 (Chicago); id., Apr. 8, 1968, at 1, col. 6 (Pittsburgh); id., col. 8 (Baltimore); cf. id., Apr. 14, 1968, at 1, col. 2 (discussing new policy of restraint. based among other things upon "use of overwhelming law enforcement manpower" and "imposition of curfers-up to 24 hours" in places of major violence). 
By contrast, in both Detroit and Newark, where curfews appeared to have little effect last summer, the number of rioters had grown uncontrollably large before the measure was imposed. ${ }^{18}$

\section{General Impact}

However useful the curfew may be, the cost of imposing it is high. Compared to the prospect of large numbers of troops patrolling a tense area or responding to a minor incident, the curfew may, at first glance, appear innocuous. In fact, it is far more drastic. The curfew is a new rule of conduct, affecting the actions of people who would not violate any other law, as well as those who would. By contrast, other antiriot tactics, such as the use of troops, are law enforcement devices intended to concentrate only upon the narrower category of persons who violnte other laws.

The extraordinarily wide and necessarily indiscriminate net cast by a curfew will sweep large numbers of people into jail;10 many of those arrested, particularly on the first night, will be innocent citizens who did not receive notice of the curfew. ${ }^{20}$ Many more innocent people

18. In Detroit, where rioting began early on Sunday morning, July 29, a clurfew was not imposed until 9 p.m. that night. During the day, available police, assisted by the National Guard, could not contain rioting, and a "Roman holiday" mood developed. N.X. Times, July 24, 1967, at 1, col. 6; $i d$., July 26, 1967, at 1, col. 7. In Newark, there were two nights of disturbances before Governor Hughes, deploring the "carnival atmospliere," called upon the National Guard and declared a 10 p.m. curfew. $t d$. July 15, 1067, at 1 , col. 7. In contrast to the rather small number of deaths and injuries in Milwaukec, sce note 17 supra, the rioting in Detroit and Newark resulted in 66 deaths and moro than 2,500 injuries. Economic losses were estimated at well over $\$ 500$ million. See Library of Congress, Riots, April 1 to July 21, 1967, at 10.11 (July 28, 1967) (Newark); Library of Gongress, Major Race Riots: July 19 to July 27, 1967, at 2 (July 29, 1967) (Detrolt).

19. No comprehensive statistics are available on the number of arrests for curfer violations during last summer or this spring. The Senate Subcommittec on Permanent Investigations tabulated nearly 30,000 arrests for all riot-related offenses in its survey of 75 disorders during 1967. Hearings on Riots, facing 15. The Riot Commission reported that 19 per cent of over 13,000 charges in 19 cities were for curfew violation. Rior Comm'N REPORT 177 n.138. The New York Times estimated that there were close to 20,000 atrests in disturbances during the week following the murder of Dr. King. N.Y. 'Times, Apr. 11, 1968 , at 35 , col. 1. The curfew accounted for more than 3,000 arrests in Washington alone. Id., Apr. 14, 1968, at 61, col. 4 .

The large influx of arrestees creates serious problems for the administration of fustice. See generally RIOT COMM'N REPORT 337-57. For a discussion of possible atdjustments in criminal procedure to deal with problems posed by riots, see Note, Riot Contral: The Constitutional Limits of Search, Arrest and Fair Trial Procedure, 68 Colum. L. REV. 85 (1968).

20. In Washington, for example, where a curfew was imposed beginning at 5:80 p.tn., it was reported that it had "no immediate effect. Few, if any of the thousands on thic streets knew of its existence." N.Y. Times, Apr. 6, 1968, at 22, col. 5. The Riot Commission placed special emphasis in its discussion of curfews on the need to provide notice. RIOT COMM'N REPORT 525. Where there are not adequate provisions for notice, a successful defense to prosecution for curfew violation may be developed because of the extratordinary nature of the measure. Cf. Lambert v. California, 355 U.S. 225 (1957). 
will temporarily be deprived of their means of economic livelihood.

Furthermore, by its restrictions on movement, a curfew severely affects the rights of entire neighborhoods to exercise the First Amendment freedoms of speech, assembly, and association. Being out of doors and free to move about are preconditions for the effective exercise of these rights. ${ }^{21}$ While the Supreme Court has not explicitly considered the right to free local movement, the harsh attitude which has been taken toward loitering and vagrancy statutes seems to reflect implicit recognition of its primacy. ${ }^{22}$ Other recent cases have increasingly recognized the right to interstate ${ }^{23}$ and extranational travel. ${ }^{24}$ The First Amendment considerations have not been discussed, but the Court has repeatedly emphasized the fundamental nature of the right to free movement. ${ }^{25}$

21. See Aptheker v. Secretary of State, 378 U.S. 500, 520 (1964) (Douglas, J., concurring): "[F]reedom of movement is the very essence of our free society .... [I]t often makies all other rights meaningful-linowing, studying, arguing, exploring, conversing, observing and even thinking. Once the right to travel is curtailed, all other rights suffer, just as when curfew or home detention is placed on a person." Free movement can arguably be classified as a penumbral First Amendment right, protected by the Ninth Amendment as is the right of privacy. Cf. Griswold v. Connecticut, 381 U.S. 479 (1965).

22. The concern primarily articulated by the Court in striking down such laws has been the possibility of arbitrary or discriminatory enforcement resulting from the broad discretion of law enforcement officers. Thus, in Shuttlesworth v. Birmingham, 382 US. 87 (1965), the Court overturned a conviction under an ordinance which might have been applied so as to permit a person "to stand on a public sidewalk .... only" at the whim of any police officer." Id. at 90. There was no discussion in the majority opinion of a right to presence on the streets or of travel, but the result of judicial cscision of loitcring ordinances is nevertheless to make more effective the right to use the streets which has been asserted in earlier opinions. See, e.g., Hague v. CIO, 307 U.S. 495, 515.16 (1939); ef. Cox v. Louisiana, 379 US. 536, 544-52 (1965). To the extent that curfews have broad exceptions for "reasonable" or "legitimate" activity or are in fact applicd discriminatorily, they may fall directly within the Shuttlesworth rationale.

For a discussion of the wide variety of constitutional arguments which may be available to challenge the "mixed bag" of offenses of status or presence, including vagrancy, prostitution, addiction, disorderly conduct, curfew violation, and others, see Amsterdam, Federal Constitutional Restrictions on the Punishment of Crimes of Stalus, Crimes of General Obnoxiousness, Crimes of Displeasing Public Officers and the Lihe, 3 Crus. Law" BuLx. 205 (1967).

23. See United States v. Guest, 383 U.S. 745, 757 (1960). Earlicr assertions of cxistence of a right to interstate travel were based upon the Commerce Clause, Edwards v. California, 314 U.S. 160 (1941); national citizenship, id. at 178 (Douglas, J., concurring); Crandall v. Nevada, 73 U.S. (6 Wall.) 35 (1867); and the Privileges and Immunities Clause, Edwards v. California, supra at 183 (Jackson, J., concurring); Twining v. New Jersey, 211 U.S. 78, 97 (1908). See also Z. Chafee, Three Human Rights in the Constrtution $184-80$ (19j6).

24. Aptheker v. Secretary of State, 378 U.S. 500 (1961); Kent v. Dulles, 357 US. 110 (1958); cf. Zemel v. Rusk, 381 U.S. I (1965) (travel ban to Cuba held on the "weightiest considerations of national security," id. at 16).

25. The Court has twice used the identical description: "Freedom of movement across frontiers in either direction, and inside frontiers as well, was part of our heritage .... [It] may be as close to the heart of the individual as the choice of what he cats, or wears, or reads. Freedom of movement is basic to our scheme of valucs." Kent v. Dulles, 357 U.S. 116, 126 (1958); Aptheker v. Secretary of State, 378 U.S. 500, 505.06 (1904) (quoting from Kent); cf. United States v. Guest, 383 U.S. 745, 757 (1966). 


\section{The Power To Impose a Curfew}

\section{A. The Control of Extraordinary Power}

In normal times, governmental regulation of the individual is based upon and limited by the police power..$^{26}$ Drastic measures which may be required by war, insurrection or natural disaster exceed the bounds of usual police power; for such measures two traditional doctrinal justifications exist-the war power ${ }^{27}$ and the power to declare martial law. ${ }^{28}$ The first power is virtually an exclusive prerogative of the fed-

26. Despite its shadowy and amorphous nature, the police power clearly has limits, although the only areas in which the courts have recently imposed limitations in practice are those where First Amendment or other fundamental rights are involved. Cf. Griswold v. Connecticut, 381 U.S. 479 (1965). One judicial concern in placing limits on the police power, which seems to render curfews legally doubtful, has been with broad measurcs that have a rational regulatory function, but also inhibit the excrcise of fundamental rights. Where the legitimate end can be achieved by narrower means, courts have struck down the unnecessarily broad measure. E.g., Aptheker v. United States, 378 U.S. 500 (1961), Shelton v. Tucker, 364 U.S. 479 (1960), Schneider v. State, 308 U.S. 147 (1939). Gurfews arc inevitably broader than the evil-violation of other laws-at which they are aimed. Just as inevitably, they stife fundamental freedoms. Ordinary law enforcement methods, where they have not been incapacitated by a riot or other catastrophe, are available as narrower means of achieving the objective at which the curfew is aimed. Only when these methods are not functioning should a curfew be considercd valid.

27. Congress and the President have traditionally been given broad discretion in taking action necessary for the conduct of war. See, e.g., Lichter v. United States, 334 U.S. 742 (1948) (recapture of excess profits realized on war contracts); Silesian-American Corp. v. Clark, 332 U.S. 469 (1947) (seizure of alien property); Korematsu v. United States, 323 U.S. 214 (1944); Bowles v. Willingham, 321 U.S. 503 (1944) (rent control); Yakus v. United States, 321 U.S. 414 (1944) (price control); Hirabayshi v. United States, 320 U.S. 81 (1949).

28. For discussion and analysis of the use of martial law in the United States, sec $\mathrm{C}$. Fairman, The Law of Martial Rule (2d ed. 1943) [hereinafter cited as Faikman]; F. Wiener, A Practical Manual of Martial Law (1940) [hereinafter cited as Wiener]; $R_{\text {. }}$ RANKIN, WHEN CiviL. LAw FaILS (1939). There is some confusion regarding the term martial law because it has been used to describe a range of extraordinary measures from military exercise of all governmental functions to use of troops, accompanied by comparatively minor restrictions on liberty and property, while civilian control is retained over most aspects of government. See p. 1568 infra.

The most drastic martial law measures have been employed by the federal government in wartime. During World War II, the military exercised complete control in Hawall. Sec J. ANTHONY, HaWAII UNDER ARMY RULE 13 (1955). The writ of habeas corpus was suspended and civilians tried in military courts during the Civil War. See Ex parte Milligan, 71 U.S. (4 Wall.) 2 (1866).

Martial law has been employed more frequently by states in dealing with dontestic violence, often in connection with labor disputes. In this context, it has generally been limited to the use of troops and occasional restrictive measures, such as dectention without traditional procedural safeguards of persons who played a significant role in the disorder. Situations in which extraordinary measures have been taken "only as to the preservation of the public peace and order, not for the ascertainment or vindication of private rights, or the other ordinary functions of government . . . and no exigency required interference with their functions," have been described as "qualificd martial law:" Commonwwealth ex rel. Wadsworth v. Shortall, 206 Pa. 165, 170-71 (1906). See generally FAiRMaN 45.47; R. RANKIN, supra, 65-84, 114-36.

The confusion concerning martial law is heightened by the fact that the chicf executive is also the commander-in-chief. Thus, the traditional dividing line between civilian and military authority, and hence between civil and martial law, is somewhat blurred. The Governor's use of the National Guard or the President's intervention with federal troops may be construed simply as action taken in support of, rather than in place of, civil control. See FaIRMan 30. 
eral government ${ }^{29}$ and requires the existence of a state of war. ${ }^{30}$ Cases on martial law, however, provide a body of law imposing standards for judicial review of extraordinary peacetime exercises of governmental power to control internal disturbances.

Eschewing the free form judicial analysis which has been applied to the police power, ${ }^{31}$ courts have inquired sharply into the specific circumstances justifying extraordinary measures. ${ }^{32}$ In fact the basic definition of martial law, "when the military authority carries on the government, or at least some of its functions," 33 carries with it two implied conditions for its use: civil government, or a part of it, must have broken down; and the President or governor, as commander-in-chief of federal or state military forces, must have intervened to establish control. The leading modern case discussing martial law, Sterling $v$. Constantin, ${ }^{34}$ examined the basic requirement of breakdown of civil control. The Governor of Texas declared martial law and dispatched state militia to certain oil fields with instructions to limit the production of oil to prevent waste. He asserted that oil producers were in a state of organized insurrection against the conservation laws. The producers obtained a temporary restraining order from a federal district court until a three-judge panel could be convened. The Governor, acting under the proclamation of martial law, ordered the militia to continue limiting production at the wells, despite the restraining order. The Supreme Court rejected the claim that a governor could exclusively determine the existence of a state of insurrection. It asserted that situations in which state power overrode private rights were always

29. Exercise of the war power by a state, absent congressional consent, is limited to situations where it is "actually invaded, or in such imminent Danger as will not admit of delay." U.S. ConsT., art. I, \& 10.

30. The application of war power in a domestic context would require a large, organized insurrection in which independence from the established government is declared. See The Prize Cases, 67 U.S. (2 Black) 635, 666-67 (1862).

31. For a discussion of the unsatisfactory nature of First Amendment theory and the bewildering variety of tests which have been and are employed in evaluating regulation of fundamental freedoms, see Emerson, Toward a General Theory of the First Amendment, 72 YALE L.J. 854 (1963). The results of the "reasonableness" test which is applicd in other areas is more comprehensible only because of the constant judicial deference to the legislative and executive judgment.

32. See, e.g., Sterling v. Constantin, 287 U.S. 378 (1932); Ex parte Mrilligan, 71 U.S. (4 Wall.) 2 (1866); Mitchell v. Harmony, 54 U.S. (13 How.) 115 (1851), and caces cited note 38 infra. But cf. Moyer v. Peabody, 212 U.S. 78 (1909). In A Yoyer, the detention by the millitary of the head of the Western Federation of Afiners for two and one half months during a labor dispute was upheld by the Supreme Court. It asserted that the governor's declaration of the existence of a state of insurrection is conclusive of that fact and concluded that "the ordinary rights of individuals must yield to what he deems the necessities of the moment." Id. at 85 .

33. FaIRMAN 30.

34. 287 U.S. 378 (1932). 
subjects for "judicial inquiry." 35 Reviewing the findings of the district court, the Court concluded that the situation could have been handled by ordinary civil means. ${ }^{36}$

Subsequent cases which applied the Sterling standard make clearer the degree of emergency which courts demand. In two cases martial law was declared after violence resulted from attempts by employers to continue business operations during strikes at their factories. The commanding officer of the National Guard ordered the factories closed, and in each case the employers obtained injunctions against further interference with their constitutional right to use their property. The rationale was that such closings were unnecessary because less drastic alternatives for insuring that the law was enforced had not been exhausted or shown inadequate. ${ }^{37}$

Judicial intervention does not end, however, when the existence of an emergency has been established. Once martial law is declared, "a vast gamut of permissible measures, differing in kind as well as in degree," 38 are available.

Where there are ... disturbances, it may, and often does suffice merely to make a display of force. If, however, the disturbance has advanced to more serious stages, the commander of the forces sent to maintain order will have to restrict circulation, establish curfew hours, disarm those carrying weapons, and exercise complete police powers in the affected area. From that point, gradations in the ascendancy of military rule . . . will readily come to mind ... until finally total martial rule is reached, which involves $\ldots$ also the operation of military tribunals for the trial and punishment of civilians within the area. ${ }^{30}$

Just as the legitimacy of a declaration of martial law is judged by its necessity, so specific measures can be employed only to the extent necessitated by the incapacity of civil control.40

35. Id. at 398.

36. Id. at 391 .

37. Strutwear Knitting Co. v. Olson, 13 F. Supp. 384 (D. Minn. 1936); Wilson \& Co. v. Freeman, 179 F. Supp. 520 (D. Minn. 1959); cf. Powers Mercantile Co. v. Olson, 7 F. Supp. 865 (D. Minn. 1934) (same rationale used as in Strutwear and Wilson; however, the court decided that civil control had broken down, all alternatives had been tricd, and martial law was justified).

38. WIENER 18.

39. Id. See also FaIRMAN 45.

40. FAIRMAN 47; WIENER 18. The military is, however, accorded a "permitted range of honest judgment," in selecting specific measures to restore order. Sterling v. Constantin, 287 U.S. 378, 399-400 (1932). The validity of specific terms of a curfew, such as its duration or application to juveniles only, and of curfew analogs, such as crowd-control meastures or store closings, should be examined at this stage. Although application of a curfew over a shorter period of time or use of a crowd-control measure rather than a curfew unquestian. 


\section{B. The Riot Curfew: Where Does It Fall?}

The curfew's place among the range of martial law devices, its historic and present use in emergency contexts, and its severe impact on constitutional rights stamps it an extraordinary exercise of authority. But though imposition of a curfew in the face of a riot looks like an exercise of martial law, there were no declarations of martial law last summer or this spring. ${ }^{41}$ Governors and city officials alike, apparently relying upon the police power, enacted curfews pursuant to declarations of states of emergency. ${ }^{42}$

It is not necessary to attempt to specify a precise line between the police power and martial law in an effort to affix a proper label to enactment of a curfew. Courts require a clear showing of necessity before they will permit martial law measures to be imposed precisely because of the severity of their impact. Similarly, when a curfew is ostensibly imposed under the police power-without a declaration of martial law-courts ought to scrutinize the justification for its imposition as closely as they examine the preconditions for martial law.

ably infringes individual liberties to a lesser extent than more drastic alternatives, the deprivations caused by any of them are nevertheless substantial enough to justify testing all by the standard of "strict necessity." Once an initial decision regarding the need for some extraordinary measures has been established, the specific action taken can be assessed, bearing in mind the greater scope of executive discretion allowed at this stage. Cf. Ex parte Milligan, 71 U.S. (4 Wall.) 2, 126-27 (1866) (discussing permissible gcographic scope of martial law).

41. In fact, efforts were apparently made to disclaim the existence of martial law. See, e.g., N.Y. Times, July 27, 1968, at 1, col. 8 (describing extraordinary actions in Detroit). The leading commentators agree, however, that martial law can exist without formal declara. tion. See FAIRMAN 30; WIENER 19-20.

42. All states provide governors with powers to act in various emergencies, although the provisions vary greatly in degree of specificity. See generally Note, Constitutional and Statutory Bases of Governor's Emergency Powers, 64 MIIcII. L. REv. 290 (1965). Miehigan's statute, for example, specifically refers to riots and the use of a curfew. AIrcri. Cossp. Luws ANN. § 10.31 (1967). New Jersey mentions neither in broad provisions defining cmergenc; and empowering the Governor to take necessary actions. N.J. STAT. AvN. App. A: 9.33.1, 9-45 (1966). Connecticut, by limiting the definition of cmergency to natural disasters or enemy attack, seems to have precluded reliance on its statute for establishment of a curfew in civil disturbances. CONN. GEN. STAT. ANN. § 28.9 (1958). If curfews are treated as martial law devices, arguments regarding authority to impose curfews are irrelcvant, but if they are evaluated as an exercise of police power, questions of delegation represent a potential basis for legal challenge under state law.

The main examples of curfews imposed by governors were those in Newark and Detroit. Most curfews were declared by mayors and other city officials. Inasmuch as mayors, unlike governors, do not serve as military commanders-in-chief, they cannot technically impose martial law. The typical situation is one in which a mayor has declared a curfew and requested the National Guard from the governor to insure its enforcement. It is conceivable, however, that a curfew, especially if applied to a restricted area before violence has occurred, could be enforced by local troops without outside assistance. In cither case, the curfew's extraordinary nature makes use of the martial law standard most appropriate in assessing its validity. Cf. note 26 supra. To the extent, however, that declaration of curfews by mayors must technically be treated as an exercise of the police power, the same potential legal pitfalls regarding proper delegation from city legislatures or directy from state legislatures exist. 
Such a test of strict necessity would not immobilize law enforcement officials. The Court in Sterling did leave open the possibility that martial law could be justified by a showing of "immediate or impending" danger ${ }^{43}$ of the development of a situation in which civil means of control would be inadequate. Thus, in applying the martial law standard to a curfew, a court could allow a city to show the presence or clear imminence of an extraordinary situation as adequate justification for a curfew. But courts must insist that the city or state official responsible for the curfew bear a heavy burden to justify it.

\section{The Test Applied}

\section{A. Preventive Curfews}

Even under a test of strict necessity, society's interest in restoring order and limiting the loss of lives and property justifies the use of a curfew as a response to a riot which has already begun. The success of curfews in riot control has led cities also to impose them in anticipation of rioting as preventive measures. The experience of last summer and this spring indicates that curfews seem most successful when imposed at an early stage in the rioting. ${ }^{44}$ Yet if a city waits until a riot has begun, much damage will have been done before personnel can be organized to make the curfew effective. ${ }^{45}$ By use of a preventive curfew government officials hope to foreclose the possibility of a riot and eliminate damage entirely.

If one could reliably predict when a riot is going to occur and be certain that the curfew would prevent it, society's interest in maintaining order would override the temporary costs to individual liberties caused by preventive curfews. It is never clear in advance, however, that a riot is going to develop. The precipitating event may be minor or major, planned or unplanned, endogenous or exogenous. Even after the fact, it is difficult to determine why a particular incident in a particular city prompted an outbreak.46

There is also uncertainty concerning the effects of a preventive cur-

43. 287 U.S. 378, 401 (1932), quoting Mitchell v. Harmony, 54 U.S. (13 How.) 115. 146.47 (1851).

44. See notes 17,18 supra.

45. The Riot Commission reported that in most disorders "violence generally flared almost immediately after the final precipitating incident. It then escalated quickly to its peak level, in the case of one-night disorders. ... Nineteen of the surveyed disorders lasted more than one night. In 10 of these, violence peaked on the first night ...." R1OT Comm'N REPORT 123.

46. See id. 117-18. 
few, which may run counter to sound antiriot policy. ${ }^{47}$ First, for those ghetto dwellers not so hesitant about violent behavior, the restrictions of such measure may trigger expectancy into action. Secondly, to many essentially nonviolent ghetto residents such a curfew may appear unjustifiable and harsh, particularly on hot summer evenings. Thile such persons might agree with and obey a riot curfew, they may join readily in massive violation of a purely preventive measure, thereby helping to create the large crowds from which a riot can quickly develop.

The uncertainties regarding prediction and effect may prevent some of the potential abuses of curfews. Even government officials who are totally insensitive to civil liberties will hesitate to risk the counterproductive effects of a summer-long curfew in the hope of preventing what could begin on any summer day. When faced with a situation in which he fears rioting more than usual, however, an official may prefer to err on the side of safety and impose an unnecessary curfew. This appears to have been the response of several cities in the aftermath of Dr. Martin Luther King's assassination. ${ }^{18}$ It is not difficult to foresee a spate of preventive curfews throughout the country during other tension-filled periods, such as when several major riots occur at approximately the same time. ${ }^{49}$

Essentially similar to a preventive curfew imposed in anticipation of an initial outbreak is the continuation of a curfew after rioting has

47. Cf. J. Spiegel, The Media in the Riot City 14-16 (paper prepared for the Lemberg Center for the Study of Violence, Brandeis University, 1967) (discussing potentially adverse results from overreaction to rioting).

48. Although it is difficult on the basis of newspaper accounts to conclude definitely that the resort to a curfew was precipitous, it appears that at least three cities uscd them as preventive devices during this period. Detroit responded to scattered looting with an $8 \mathrm{p} . \mathrm{m}$. to $5 \mathrm{am}$. curfew, which was continued through the weekend. although "no riot [developed] in the city." N.Y. Times, Apr. 7, 1968, § 2, at 63, col. 6. In Aremphis, Tenn., where a curfew had been imposed the week before as a result of rioting in connection with a sanitation workers' strike, the measure was reimposed on Thursday, the night of Dr. King's death. Id., Apr. 5, 1968, at 1, col. 8. There were no reports of rioting then or later. A curfew was also placed on Mobile, Ala., Friday night in response to "sporadic" vandalism $I d$. Apr. 8, 1968, at 31, col. 4. Some of the nine curfews which were imposed on North Carolina cities after Dr. King's death may also have been preventive. It was reported that Greensboro and Raleigh were "focal points" of violence. Id., Apr. 7, 1968, at 63, col. 7. No details were provided regarding the reason for curfews in the other cities. See id., Apr. 9, 1968 , at 36 , col. 7.

The crowd-control ordinances employed by Philadelphia both last summer and this spring, see note 6 supra, also appear to have been preventive in nature. See N.Y. Times, Apr. 9, 1968, at 27, col. 3; id., July 29, 1967, at 11, col. 1 .

49. During the latter part of July 1967, the two worst riots of the summer occurred, Newark and Detroit. Rioting began in Newark on July 12. Id., July 13, 1967, at 1, col. 2 . The National Guard began to withdraw on July 17. Id., July 18, 1967, at 1 , col. 4 . Detroil's riot began July 23. Id., July 24, 1967, at 1 , col. 6. It appeared to be ending on July 27 . Id., July 28, 1967, at 1, col. 6 .

More than 60 per cent of the 164 disorders reported by the Riot Commission occurred during July. RIOT COMM'N REPORT 114. 
subsided. Here the likelihood of abuse is greater still, ${ }^{50}$ for added to the impulse to err on the side of safety is inertia.

The strict necessity test drawn from the martial law analogy menns that government officials imposing curfews must be prepared to show imminent danger of a breakdown of civil control. The enormous difficulties of predicting a riot and pinpointing the time of a return to normal, compounded by the potential for terrible losses to life and property, indicate that considerable indulgence must be given to executive discretion. A curfew should seldom be enjoined before the first feared night has passed; to prevent clear abuses it should be sufficient at this stage to require the government to file affidavits which present a justification for the extraordinary measure. But as nights without rioting pass, the court's responsibility to protect fundamental liberties requires it to intervene unless officials can show a clear trend of in. creasing tension and danger.

\section{B. Geographic Scope}

Once it has been decided that a curfew is justified, its permissible geographic scope remains in question. When only selected areas of a city fall under a curfew-black ghettos, for example-a court must be careful that it is not faced with a case of discriminatory law enforcement. From the point of view of the strict necessity test, however, the interesting question concerns the validity of city-wide curfews. ${ }^{51}$

For purely preventive reasons, an official is justified in placing a curfew upon areas of the city to which a riot may spread; 52 but he may

50. It is as difficult on the basis of newspaper accounts to designate citics which have abused the curfew by maintaining it too long as it is to designate those which have im. posed it prematurely. However, there appear to be some relatively clear examples. Last. summer, Milwaukee, which imposed a curfew on July 30, maintained it until August 6 although there was little disturbance after the second day. See N.Y. Times, Aug. 7, 1967, at 22, col. 5. Detroit initially lifted its curfew after the fourth day, but reimposcd it to prevent sightseers from entering the riot area. Id., July 28, 1967, at 1, col. 6. It was not finally lifted until nine days after it had originally been declared. Id., Aug. 2, 1967, at 16, col. 5. In Trenton, New Jersey, this spring, a curfew was imposed on Tuesday, April 9. It was continued through the weekend although there was no violence after Tuesday and the National Guard was withdrawn on Friday. Cf. id., Apr. 13, 1968, at 11, col. 8. Washington's curfew may also have been employed longer than necessary. The curfew was first imposcd on April 5. Id. Apr. 6, 1968, at 1, col. 8. Although it was reported as carly as April 8 that the rioting was ending, see id., Apr. 8, 1968, at 1, col. 6, the curfew was not finally lifted until April 12. Id., Apr. 13, 1968, at 13, col. 3.

51. Among those imposing city-wide curfews have been Detroit, Milwaukee, Newark (though originally only applied to one-third of the city), Syracuse, and Wilmington, Del. last summer and Baltimore, Chicago, Detroit, Kansas City, Mo., Memphis, Nashville, Pittsburgh, and Raleigh this spring. Only a few cities, including Atlanta, Phoenix, and Tampa, tailored their curfews to a limited geographic area last summer. Apparently only Newark used a geographically limited curfew this spring.

52. The Riot Commission recommended that curfew legislation be drafted to "enable curfews to be imposed in adjoining cities in order to ensure coverage of the entire disorder 
also have a variety of reasons for wishing to impose a comprehensive curfew which will reach clearly identifiable areas in which the likelihood of extraordinary violence is nil. For example, (1) giving adequate notice of the boundaries of a limited curfew will be more difficult than notice of a general curfew; (2) assigning police or National Guardsmen to cordon off a restricted area may subtract more personnel from the riot area than would policing a general curfew; (3) in many unthreatened areas a city-wide curferw may be policed by fewer men than are ordinarily needed for general law enforcement, thus freeing others for duty in rioting areas; (4) the apparent discrimination inherent in limiting a curfew to black neighborhoods may aggravate the racially based bitterness which feeds most riots.

As early as Ex parte Milligan the Supreme Court established that martial law must be limited to the geographic area in which it is necessary. ${ }^{53}$ This principle presumptively forbids the use of a curfew in those portions of the city where there is no rioting or imminent danger of breakdown of civil control; considerations of administrative efficiency alone cannot justify imposition of a curferw on nonriot areas any more than they could justify a curfew when no riot threatened the city at all. A city-wide curfew covering unthreatened areas is justifiable only to the extent that failure to take advantage of the resulting administrative efficiencies can be said to jeopardize seriously the effort to put down or control the present or expected riot. The difficulty of calculating such effects and the institutional problem of judicial attempts to designate specific curfew bounds suggest that executive discretion will be given greater scope as to geographic limits than as to imposition or continuation of a curfew. ${ }^{\text {th }}$ Nevertheless, the strict necessity test imposes on courts a duty to prevent clear abuses by requiring officials to present, as time passes, increasingly articulated and convincing justifications for the geographic scope of curfews.

area." RIOT COMM'N REPORT 525. It did not define "entire disorder area," although the reference may have been to the large riots in Detroit and Newark which spread to neighboring communities. The Commission unfortunately did not parallel its concern for providing legislation that would make curfews brozd enough geographically by suggestions regarding the need to take care that curfews are not too broad.

53. 71 U.S. (4 Wall.) 2 (1866). The Court held military trial of civilians in Indiana illegal because civil courts trere capable of functioning. In that area, there was at best a "threatened invasion." Martial law could be valid only where there was an "invasion ... such as effectually close[d] the courts and depose[d] the civil administration." Id. at 127.

54. Especially on the first night, when manpower shortages are likely to be acute, an official may be justified in imposing the curfew city-wide in order to concentrate manpower in riot areas. In addition, there may at first be substantial uncertainty regarding where further outbreaks are likely. The official may conclude that immediate danger compels him to employ the simpler and quicker expedient of a possibly overinclusive measure. As time progresses, however, resulting in availability of more men and clearer knowledge of areas of danger, this argument for a city-wide curfew becomes less convincing. 